\title{
PATENTS ON LIFE: A BRIEF VIEW OF HUMAN MILK COMPONENT PATENTING
}

By Valerie McClain

\section{ABSTRACT}

Academic research on human milk, often funded by US governmental grants, has shown that this live substance has health benefits for infants. Since the 1980's, researchers have been looking for the magic bullets in human milk that bestow various health benefits to breastfed infants. Molecular cloning/genetic engineering has provided researchers with a way to create components in the lab so that formula-fed infants can receive some health advantages possibly similar to those enjoyed by breastfed infants. Researchers believe that their inventions not only benefit premature and full-term infants but also may benefit children and adults in other applications.

Research into human milk and its health benefits has resulted in numerous patents. This paper offers a brief glimpse at six of the many U.S. patents on human milk components: human lactoferrin, human milk oligosaccharides, the probiotic derived from human milk-Lactobaccillus reuteri, and 3 of the Prolacta Bioscience (the for-profit milk bank that developed the first human milk-based infant formula) patents. Questions are briefly raised about these patents. Are there patents on life? Is this biopiracy?

\section{INTRODUCTION}

"Over the last two decades, under the influence of corporations, patent laws have taken a different direction-from protecting the interests of genuine inventions and ideas to ownership of life and control over survival essentials like seed and medicine." (Shiva, 2016)

How can life be patented? What do we mean by the word, life? A microbiologist might simply state that life is anything with DNA. A quantum physicist might give a long-winded philosophical speech about Schrödinger's cat being both alive and dead. Some may describe life in terms of energy, chi or life force. Religious leaders may say life is the breath of God. Biologists say that, "life is defined by organisms whose properties are metabolism, reproduction and adaptation to its surroundings." (Biology 
online, 2017)) The definition of life is often dependent upon a person's worldview, their religious and/or scientific beliefs.

What is a patent? The US Patent and Trademark Office defines it in several ways. "A patent is a limited duration property right [generally 20 years] to an invention, granted by the US Patent and Trademark Office in exchange for public disclosure of the invention." (US Patent and Trademark Office, 2017) They go on to state that, "An invention is patentable if it is novel, useful and non-obvious." (US Patent and Trademark Office, 2015) Essentially, a patent gives a period of time to an inventor during which he/she has a monopoly on selling his or her product.

Patents may include: genes, cells, cell lines, and tissues which can be taken from: seeds, plants, trees, animals, and even humans. (King and Stabinsky, 1999) How is it legal to patent life? For several centuries in the US, products of nature were not patentable. But in 1980 the US Supreme Court in the case of Diamond v. Chakrabarty determined that a genetically engineered one-celled bacterium was patentable. (Robinson et al., 2005) This decision, in conjunction with the Bayh-Dole Act in 1980 (Government Publishing Office, 2011), which allowed publicly funded research to be patented as private innovation, opened the door for industries and scientists to apply for patents on various life forms.

US biotech companies, US government agencies, and universities began to apply for patents on seeds, plants, and trees. A controversial example has involved several medicinal plants from India. Rice Tec patented varieties of Basmati rice. The WR Grace and Company and the US Department of Agriculture patented the Neem tree. The University of Mississippi Medical Center made patent claims on India's turmeric for wound healing. (Bhargava, 2009) For thousands of years India has been using those particular seeds, plants and trees medicinally. These patents were legally challenged by India and a few of them, Neem and turmeric, were actually revoked. (Jayaraman, 1997) (Hellerer and Jarayaman, 2000) Another example was Nestlé applying for a US patent on the seeds of Nigella sativa. Known as black cumin Nigella sativa, black seed, in Arabic cultures means the, "seed of blessing," or in Islam, "a remedy for all diseases except death." (Ji, 2013) The patent application

"The Bayle-Dole Act, passed on December 12, 1980, created a uniform policy among the many federal agencies that fund research, enabling small business and nonprofit organization-including universities-to retain title to inventions made under federally funded research programs." United States Patent and Trademark Office https://www.uspto.gov/aboutus/news-updates/uspto-marks-30thanniversary-bayh-dole-act 
was to treat and/or prevent food allergies using Nigella sativa as well as other components. (Nutten et al., 2010)

Such patents are labeled biopiracy by environmental groups and developing countries. Jana Rose at The Conversation website, a Grenoble Ecole de Management (GEM) and US universities funded website, describes biopiracy,

“Biopiracy happens when researchers or research organizations take biological resources without official sanction, largely from less affluent countries or marginalized people." (Rose, 2018)

While seeds and plants were of enormous interest to researchers in the United States and helped set the stage for patenting life, human milk and its components have been and continue to be of research interest resulting in patents. During the 1980's, through the efforts of Thorsten A. Fjellstedt of the National Institute of Child Health and Human Development (NICHD), researchers began to receive financial support in the form of grants by the NICHD for research on the physiology of lactation and human milk components. (Goldman, 2018) (NIH Guide for Grants and Contracts, 1984) The combination of government support and the passing of the Bayle-Dole Act of 1980 would open a door to the patenting of human milk components.

Biopiracy is not just the appropriation by wealthier nations of indigenous knowledge from another country. It can also happen when corporations/researchers patent human cells. Most people are unaware of the value of their cells to the medical-industrial complex. Notable cases are John Moore whose cells became the Mo cell line worth millions of dollars and Henrietta Lacks whose cervical cancer cells became the HeLa cell line. While the original researcher did not patent the cell line, other researchers have applied for and received thousands of patents. (Devine, 2018) (Khan, 2011)

\section{SIX EXAMPLES OF HUMAN MILK COMPONENT PATENTS}

There are numerous patents and patent applications at the US Patent and Trademark Office that make claims on human milk component patents. (McClain and Linnecar, 2013) Most of those claims use genetic engineering techniques to invent a human milk component but some patents seem to be making composition claims on a real human milk component. The following 6 patents are remarkable for either the claims they make regarding human milk components or because their inventions impacted the development of a number of products in the US and in Europe. 


\section{Baylor College of Medicine lactoferrin patents}

In Texas in the 1980's, Baylor College of Medicine applied for and was granted a patent in which they made claims on the real human milk component, lactoferrin, as well as bovine lactoferrin for use in infant formula. The purpose of the patent was to promote the growth of the gastrointestinal tract of newborns to reduce diarrhea and short gut syndrome. Lactoferrin would be added to infant formula. The patent states, "In a large number of human newborns, who are not nursed by the mother but are placed on an infant formula, this growth of the gastrointestinal tract during the first few days may not occur, and, as a result, the infant is predisposed to chronic intractable diarrhea which must be managed for a period of three or more months at considerable expense and discomfort to the infant." (Nichols and McKee, 1987)

During the 1990's research interest in human lactoferrin increased at Baylor College of Medicine. Researchers at Baylor College of medicine had isolated and invented a way to produce human lactoferrin in a lab by molecular cloning (genetic engineering).

"The full-length cDNA encoding human lactoferrin has been isolated, and the analysis has been completed. The cDNA sequence has been confirmed as human lactoferrin cDNA by comparison of the deduced amino acid sequence with the published amino acid sequence of hLF [human lactoferrin]." (Conneely, et al., 1993)

The ability to isolate and create the code for human lactoferrin meant that this could be used by a number of different biotech researchers and industries. The genetic code could be used by the dairy industry to produce human lactoferrin in cow's milk, or by various biotech industries using plants like rice or barley, or single cell microbes: bacteria, yeast, fungus, and algae. Agennix, a biotech company formed by Baylor College of Medicine researchers (some of the same co-inventors to the patents that isolated human lactoferrin); used various fungi derived from Aspergillus to manufacture human lactoferrin. (Sun, 1999)

The investment and interest by the biotech industry in recombinant (genetically engineered) lactoferrin has continued to grow. The initial Baylor patent suggested products that would result from their inventions.

Terms used in Genetic Engineering (Nicholl, 1994)

cDNA (Complementary DNA)" is DNA that is made by copying mRNA (Messenger RNA) using the enzyme reverse transcriptase."

Clone- "A colony of identical organisms; often used to describe a cell carrying a recombinant DNA fragment."

DNA (Deoxyribonucleic acid)" is the primary genetic material in all organisms aprt from some RNA viruses."

mRNA (Messenger RNA) "The ribonucleic acid molecule transcribed from DNA that carries the codons specifying the sequence of amino acids in a protein."

Recombinant DNA-“A DNA molecule made up of sequences that are not normally joined together." 
"The LF [ Lactoferrin] produced by recombinant methods can be used in a variety of products including human or animal foods, as therapeutic additives to enhance iron transport and delivery, and for the viricidal and bactericidal qualities, as additives for eyedrops, contact lens and other eye care solutions, topical skin care products, eardrops, chewing gum and toothpaste." (Conneely, et al., 1993)

Lactoferrin has been added to various infant formulas around the world. The products suggested in the Baylor patent are now in the marketplace; from eye drops to toothpaste. Even meat is being treated with a form of lactoferrin to inactivate pathogens. (Duran, et al., 2017)

\section{BioGaia Bioscience patent on Lactobacillus reuteri}

In Sweden, BioGai researchers were looking for a bacterium to use as a probiotic. They settled on Lactobacillus reuteri, a known bacterium with antibiotic properties. BioGaia researcher, Dr Ivan Casas, went to Peru to a village in the Andes where he obtained samples of breast milk from Indian mothers. It was examined and deposited with the ATCC (American Type Culture Collection, a biorepository); and tagged as ATCC PTA-6475. It became known as, Lactobacillus reuteri Protectis. (Halliday, 2010)

Senior VP of Research at BioGaia at that time was Eamonn Connolly. He is listed as the only inventor to the patent associated with this particular Lactobacillus reuteri derived from human milk. The first claim in this patent appears to be a claim of composition of the bacteria derived from the Peruvian Indian mother(s), "1. A biologically pure culture of Lactobacillus reuteri ATCC PTA-6475." (Connolly, 2005)

BioGaia has partnered with Nestlé to provide this probiotic. It appears to be financially advantageous. Whether the Peruvian Indian mothers who donated their breast milk were compensated or compensated adequately is not known. According to a website article in 2012, Biospace states, "The agreements include the entry by Nestle into a perpetual licence to use BioGaia's patented Lactobacillus reuteri in infant nutrition products for EUR 50.8 million." (Biospace, 2012)

\section{Nestlé patents on osteoprotegerin}

Nestlé SA has numerous infant formula patents at the US Patent and Trademark Office two of which have the same title. One patent makes claims on methods to create their invention. (Vidal. 2005) The other patent makes the following claim, "A food material comprising an osteoprotegerin isolated from human or bovine milk or colostrum, wherein the osteoprotegerin includes a glycosylation pattern giving rise to a polypeptide have a molecular weight of approximately $130 \mathrm{kDa}$, wherein the osteoprotegerin has been added to the food material and wherein said food material is selected from 
the group consisting of yogurt, curd, cheese, fermented milks, milk based fermented products, ice-creams, fermented cereal-based products, milkbased powders, infant formulae and pet food." (Vidal, 2003)

Nestlé SA denies on their website that they are patenting human breast milk. (Nestlé, 2018) Technically a claim on human milk would be considered too broad to be accepted as a patent. The patent states in their claims the possibility that they will use osteoprotegerin isolated from human milk.

\section{Abbott's patent on Human Milk Oligosaccharide}

Abbott owns a number of infant formula patents that use human milk oligosaccharides (HMOs) to improve their product. This particular patent represents the value this company places in adding this human milk component to their infant formula. The patent begins by stating,

"Breastfeeding has been associated with enhanced development and balanced growth and maturation of the infant's respiratory, gastrointestinal and immune systems, thereby providing protection of the infant to infection and inflammatory diseases." (Buck et al., 2011)

This patent also states the possible origins of the HMOs, isolated from the milk of humans, cows, sheep, pigs or monkeys. Or they might use genetic engineering or synthetic techniques or combinations of methods. Thus, the patent does not disclose exactly what they will be using, but most of the language in the patent is a discussion on human milk.

Currently Abbott has two US infant formulas that have HMOs, Similac Pro Advance and Pro Sensitive. (Abbott Nutrition, 2016) Nestlé Spain is planning to add their "breast milk oligosaccharides" to their infant formulas. (Cornall, 2017) Supposedly they are identical to human milk oligosaccharides. Unless they are getting those oligosaccharides from a human donor milk bank, it would seem probable that the oligosaccharides that are manufactured by Nestlé Spain are not identical to human milk.

\section{Prolacta Bioscience, First For-Profit Milk Bank and their patents}

Lastly, one of the more interesting developments has been the founding of a company in California by Elena M. Medo. The company, Prolacta Bioscience, calls itself a for-profit milk bank. Prolacta Bioscience manufactures human milk-based infant formulas designed for premature and very premature infants. (Prolacta Bioscience, 2018a) The FDA designates and regulates Prolacta's products as "exempt infant formulas." (US FDA, 2017) Elena Medo left Prolacta Bioscience in 2009 and started Medolac, a company that makes sterile human milk that has a shelf-life of a few years. Their Mother's Milk Cooperative provides the donor milk for the company. (Daisyme, 2017) 
The Prolacta Bioscience patents show a broad interest in not just inventing a human milk-based formula for premature infants but in creating other products. Their donor milks are pooled, pasteurized, fats and permeate (contains oligosaccharides) are skimmed off, vitamins/minerals are added and the product is frozen. Human milk fat will be used with the intention of manufacturing enteral or parenteral nutrition, for example, total parenteral nutrition. (Medo and Eaker, 2013) The human milk oligosaccharides (permeate) will be separated from the milk and used as nutritional support for preterm and full-term infants, children, and adults. (Fournell et al., 2009)

One question is whether a highly processed human milk-based formula is equivalent to the nutritional and immunological value of milk made in the human mammary gland. Another, whether it is better than the preterm infant formula available in neonatal intensive care units.

Medo's first patent for Prolacta Bioscience, explaining that the reason for the existence of the company is the health risks of infant formula. "It has been suggested that the exposure of an infant to any foreign proteins, such as bovine protein, during the first few days of life will increase the infant's chance of becoming afflicted with juvenile diabetes. Other ill effects include allergies, lowered immunity, gastrointestinal disorders, respiratory disease and other associated etiology. Although much effort has been made to improve synthetic infant milk formulas, attempting to make them more closely simulate mother's milk, the presence of living organisms and other 'species-specific' cells that act in a way to trigger other disease preventing mechanisms in the infant, these efforts have proven futile." (Medo, 2009)

The Prolacta Bioscience patents appear to make no claims on human milk components. Their patents relate to methods of creating human milk products. Does a corporation have the ethical right to create a product made from human milk donations? While donor mothers are given some sort of compensation from Prolacta, is the compensation fair?

Prolacta's website states their commitment to donors and their only breastfeeding tip is on increasing a milk supply. (Prolacta Bioscience, 2018b) An increased milk supply benefits Prolacta's ability to procure more milk. Most mothers of preterm babies in neonatal intensive care units are pumping only because breastfeeding is not given a high priority. (Pineda, 2011) Will human milk-based products encourage breastfeeding or will it encourage more pumping of human milk? Will the availability of a human milk-based formula discourage breastfeeding?

\section{CONCLUSIONS}

The corporate desire for free and natural resources to commercialize has led to the commodification of human milk components, and even human milk 
itself. The six patents discussed are owned by two infant formula companies, one probiotic company, one medical college, and a for-profit milk bank.

There are many more human milk component patents owned by other infant formula companies, medical schools, universities, drug companies, and even the US Government. Research and patenting on lactoferrin has resulted in numerous products with this added component, from toothpaste to infant formula. The patenting is based on the antibacterial and anti-viral properties of human lactoferrin. Probiotics has become a financially lucrative addition to foods and particularly infant formula foods.

One issue that gets little attention is the extent to which biopiracy is involved in such patents. BioGaia Bioscience's probiotic derived from Peruvian breastfeeding mothers appears to be such a case. Parents are unaware that human milk contains its own probiotics and that some Nestlé formulas contain a cloned bacterium derived from human milk. HMOs are considered prebiotic by infant formula companies. Yet parents are unaware that human milk contains a far larger variety of oligosaccharides that create a healthy gut and immune system. Prolacta Bioscience, a for-profit human milk bank, has created a human milk-based infant formula for premature infants. Will breastfeeding survive against the competition now, not only from cow's milk-based and soy milk-based infant formulas, but also human milk-based infant formula? The commercial control over what women produce in their breasts seems to be in the hands of the corporate world.

The public may be largely ignorant of the commercial value of human milk and the scientific reasons for its value. Patenting of human milk components is predicated on the belief that some women can't or won't breastfeed, and the superiority of human milk. The question is how many women can't or won't breastfeed? Do women have control over infant feeding decisions when human milk is commodified? History shows us that control over women and their bodies is damaging not to just women and families but to society. Tony Morrison's Pulitzer Prize-winning novel, Beloved, portrays the character, Sethe, a newly freed slave in America's post-Civil War. Sethe mourns the loss of her mother's milk. She says, "There was no nursing milk to call my own. I know what it is to be without the milk that belongs to you." (Morrison, 1987)

What will be the biological and social impact of patenting? Will the commercialization of human milk components decrease breastfeeding initiation and duration? Like Sethe, will future generations feel the loss of their own mother's milk? 


\section{REFERENCES}

Abbott Global Nutrition. 2016. Why Human Milk Oligosaccharides Are the Next Big Breakthrough. Accessed March 6, 2018.

http://www. nutritionnews. abbott/healthy-moms-babies/breakthroughs-ininfant-nutrition.html

Bhargava D. 2009. Patent Act: Biopiracy of Traditional Indian Products-An Overview. Accessed February 22, 2018.

https://www. countercurrents.org/bhargava140709.htm

BioGaia. 2018. BioGaia's probiotic strains. Accessed March 4, 2018. https://www. biogaia.com/probiotics/biogaias-probiotic-strains/

Biology online. 2017. Life. Biology online Definitions. Accessed March 10, 2018. http://www. biology-online.org/dictionary/Life

Biospace. 2012. Nestle SA I nvests €50 Million in 5-Year Probiotic Licensing Deal with BioGaia. Accessed March 4, 2018.

https://www. biospace.com/article/releases/nestle-sa-invests-50-million-in5-year-probiotic-licensing-deal-with-b-biogaia-b-/

Buck R, Duska-McEwen G, Davis S, et al. 2011. Method of using human milk oligosaccharides for improving airway respiratory health. US Patent and Trademark Office. Patent \#8802650. http://patft.uspto.gov/netacgi/nphParser?Sect $1=$ PTO $\&$ Sect $2=$ HI TOFF $\& d=$ PALL $\& p=1 \& u=\% 2$ Fnetahtml\% 2 FPTO $\% 2$ Frchnum. htm\&r $=1 \& \mathrm{f}=\mathrm{G} \& \mathrm{l}=50 \& \mathrm{SI}=8802650 . \mathrm{PN} . \& O S=\mathrm{PN} / 8802650 \& \mathrm{RS}=$ PN/8802650

Conneely O, Headon D, O'Malley B. 1993. Production of recombinant lactoferrin and lactoferrin peptides using CDNA sequences in various organisms. US Patent and Trademark Office. Patent \#5571691.

http://patft.uspto.gov/netacgi/nphParser?Sect $1=$ PTO1 \&Sect $2=$ HITOFF $\& d=$ PALL $\& p=1 \& u=\% 2$ Fnetahtm $1 \% 2$ FPTO $\% 2 F s r c h n u m \cdot h t m \& r=1 \& f=G \& l=50 \& s 1=5571691 . P N . \& O S=P N / 5571691 \& R S=$ PN/5571691

Connolly E. 2005. Selection and use of lactic acid bacteria for reducing inflammation in mammals. US Patent and Trademark Office. Patent \#7344867. http://patft.uspto.gov/netacgi/nphParser?Sect $1=$ PTO1 $\&$ Sect $2=$ HITOFF $\& d=$ PALL $\& p=1 \& u=\% 2$ Fnetahtml $\% 2$ FPTO $\% 2$ Fsrchnum. htm \& $\mathrm{r}=1 \& \mathrm{f}=\mathrm{G} \& \mathrm{I}=50 \& \mathrm{~s} 1=5571691 . \mathrm{PN} . \& O S=\mathrm{PN} / 5571691 \& \mathrm{RS}=$ PN/5571691 
Cornall J . 2017. Nestle Spain develops first infant formula with two breast milk oligosaccharides. Dairy Reporter. Accessed March 6, 2018.

https://www. dairyreporter.com/Article/2017/07/05/Nestle-Spain-developsformula-with-two-breast-milk-oligosaccharides

Daisyme P. 2017. Women Empowering Women: Preterm Babies and the Story of Medolac. Entrepreneur. Accessed March 9, 2018. https://www.entrepreneur.com/article/288199

Devine C. 2018. Tissue Rights and Ownership: Is a Cell Line a Research Tool or a Person? The Columbia Science \& Technology Review blog post.

Accessed February 26, 2018. http://stlr.org/2010/03/09/tissue-rights-andownersharch-tool-or-a-person/

Duran A and Kahve H. 2017. The Use of Lactoferrin in Food Industry. Academic Journal of Science 07(02): 89-94. https://www. researchgate.net/publication/317258941_THE_USE_OF_LACTO FERRIN_IN_FOOD_INDUSTRY

Fournell J, Eaker S, Elster S et al. 2009. Human milk permeate compositions and methods of making and using same. US Patent and Trademark Office. Patent \# 8927027. http://patft.uspto.gov/netacgi/nph-

Parser? Sect $1=$ PTO1 \&Sect $2=$ HITOFF $\& d=$ PALL $\& p=1 \& u=\% 2$ Fnetahtm $\% 2$ FPTO $\% 2$ Frchnum. htm\&r=1\&f=G\&l=50\&s1=8927027.PN.\&OS=PN/8927027\&RS = PN/8927027

Goldman A. 2018. History of ISRHML. Website. Accessed March 29, 2018. https://www.isrhml.com/i4a/pages/index.cfm?pageid=3291

Government Publishing Office (US), 2011. Patent Rights in Inventions Made with Federal Assistance [Bayh-Dole Act]. Title 35, chapter 18, page 88. https://www.gpo.gov/fdsys/pkg/USCODE-2011-title35/pdf/USCODE-2011title35-partll-chap18.pdf

Halliday J. 2010. Nestlé's Reuteri demand is boon for BioGaia. Nutral ngredients. Accessed March 4, 2018. https://www. nutraingredients.com/Article/2010/08/17/Nestle-s-Reuteridemand-is-boon-for-BioGaia

Hellerer U and Jarayaman KS. 2000. Greens persuade Europe to revoke patent on neem tree. Nature 405:266-267 doi: 10.1038/3512778

Jayaraman KS. 1997. US Patent Office Withdraws Patent on Indian Herb. Nature 389, 6(04 September 1997) doi: 10.1038/37838 
Ji S. 2013. Black Seed-'The Remedy for Everything but Death.'

GreenMedInfo. Website. Accessed March 10, 2018.

http://www.greenmedinfo.com/blog/black-seed-remedy-everything-death

Khan FA. 2011. The Immortal Life of Henrietta Lacks. Review. JIMA, 43(2): 93-94. doi 10.5915/43-2-8609

King J and Stabinsky D. 1999. Patents on Cells, Genes, and Organisms Undermine the Exchange of Scientific Ideas. Council for Responsible Genetics. Website. February 5, 1999. Accessed March 10, 2018. http://www.councilforresponsiblegenetics.org/ViewPage. aspx?pagel d=171

McClain V and Linnecar A. 2013. Patents and the Code: Where Do They Clash? IBFAN ICDC Legal Update, pg. 2-4. Accessed March 10, 2018. http://www.ibfan.org/art/LU-July2013.pdf

Medo EM. 2009. Method of producing nutritional products from human milk tissue and compositions thereof. US Patent and Trademark Office. Patent \# 7914822. http://patft.uspto.gov/netacgi/nph-

Parser? Sect $1=$ PTO1 $\&$ Sect $2=$ HITOFF $\& d=$ PALL $\& p=1 \& u=\% 2$ Fnetahtml $\% 2$ FPTO $\% 2 \mathrm{Fsrchnum} \cdot \mathrm{htm} \& \mathrm{r}=1 \& \mathrm{f}=\mathrm{G} \& \mathrm{l}=50 \& \mathrm{~S} 1=7914822 . \mathrm{PN} . \& O S=\mathrm{PN} / 7914822 \& \mathrm{RS}=$ $\underline{\mathrm{PN} / 7914822}$

Medo EM and Eaker S. 2013. Compositions of human lipids and methods of making and using same. US Patent and Trademark Office. Patent \#8821878. http://patft.uspto.gov/netacgi/nphParser?Sect $1=$ PTO $\&$ Sect $2=$ HITOFF $\& d=$ PALL $\& p=1 \& u=\% 2$ Fnetahtml $\% 2$ FPTO $\% 2 \mathrm{Fsrchnum} \cdot \mathrm{htm} \& \mathrm{r}=1 \& \mathrm{f}=\mathrm{G} \& \mathrm{l}=50 \& \mathrm{~S} 1=8821878 . \mathrm{PN} . \& O S=\mathrm{PN} / 8821878 \& \mathrm{RS}=$ PN/8821878

Morrison Toni. 1987. Beloved. New York: Random House. pg 236.

National Research Council. 1984. Genetic Engineering of Plants: Agricultural Research Opportunities and Policy. Washington, DC: The National Academies Press. https://doi.org/10.17226/10.

Nestlé Global. 2018. Is Nestlé trying to patent human breast milk? Website. Accessed March 8, 2018. https://www.nestle.com/ask-nestle/healthnutrition/answers/is-nestle-trying-to-patent-human-breast-milk

Nicholl D. 2002. An Introduction to Genetic Engineering. $2^{\text {nd }}$ edition. Cambridge: Cambridge University Press, Glossary.

Nichols B, McKee K. 1987. Lactoferrin as a dietary ingredient promoting the growth of the gastrointestinal tract. US Patent \& Trademark Office. Patent \# 4977137. http://patft.uspto.gov/netacgi/nph-

Parser?Sect $1=$ PTO1 $\&$ Sect $2=$ HITOFF $\& d=$ PALL $\& p=1 \& u=\% 2$ Fnetahtm $\% 2$ FPTO 
\%2Fsrchnum.htm\&r=1\&f=G\&l=50\&s1=4977137.PN.\&OS=PN/4977137\&RS= PN/4977137

NIH Guide for Grants and Contracts. 1984. Request for Applications 85-HD02-The Physiology of Lactation and the Biology of Human Milk. Page 12-14. Accessed March 29, 2018. https://grants.nih.gov/grants/guide/historical/1984_11_09_Vol_13_No_12.p df

Nutten S, Philippe D, Mercenier A, et al. 2010. Opioid receptors stimulating compounds (Thymoquinone, Nigella sativa) and food allergy. US Patent \& Trademark Office. Patent Application \#20120142580. http://appft.uspto.gov/netacgi/nphParser?Sect1 =PTO1\&Sect2 =HITOFF $\& d=P G 01 \& p=1 \& u=\% 2$ Fnetahtm $1 \% 2 F P T O$ $\% 2 F s r c h n u m \cdot h t m|\& r=1 \& f=G \&|=50 \& s 1=\% 2220120142580 \% 22 . P G N R . \& O S=$ DN/20120142580\&RS $=$ DN/20120142580

Pineda R. 2011. Direct breast-feeding in the neonatal intensive care unit: is it important? J Perinatal 8:540-5 doi: 10.1038/jp.2010.205

Prolacta Bioscience. 2018a. Why Choose Prolacta? Website. Accessed March 19, 2018. http://www.prolacta.com/

Prolacta Bioscience. 2018b. Breastfeeding Tips for Increased Milk Supply. Website. Accessed April 4, 20118. http://www. prolacta.com/nursingyourbaby

Robinson D and Medlock N. 2005. Diamond v. Chakrabarty: A Retrospective on 25 years of Biotech Patents. Intellectual Property \& Technology Law Journal 17(10): 12-15.

https://bannerwitcoff.com/_docs/library/articles/Chakrabarty.pdf

Rose J. 2018. Biopiracy: When indigenous knowledge is patented for profit. Website. Accessed March 10, 2018. https://theconversation.com/biopiracywhen-indigenous-knowledge-is-patented-for-profit-55589

Shiva V. 2016. Biopiracy: The Plunder of Nature and Knowledge. $2^{\text {nd }}$ ed. Berkeley: North Atlantic Book.

Sun X, Baker H, Shewry S, et al. 1999. Structure of recombinant human lactoferrin expressed in Aspergillus awamori. Acta Crystallogr D Biol Crystallogr, D55:403-407. DOI: 10.1107/S0907444998011226

U.S. Food \& Drug Administration. 2017. Exempt Infant Formulas Marketed in the United States By Manufacturers and Category. Silver Spring, MD: FDA Accessed March 10, 2018. 
https://www.fda.gov/Food/GuidanceRegulation/GuidanceDocumentsRegulato ryl nformation/I nfantFormula/ucm106456.htm

US Patent and Trademark Office. 2012. USPTO Marks $30^{\text {th }}$ Anniversary of Bayh-Dole Act. Website. Accessed March 10, 2018.

https://www.uspto.gov/about-us/news-updates/uspto-marks-30th-

anniversary-bayh-dole-act

US Patent and Trademark Office. 2015. Novelty And Non-Obviousness, Conditions for Obtaining A Patent. General information concerning patents. Alexandria, Virginia: US Patent and Trademark Office. Accessed March 10, 2018. https://www. uspto.gov/patents-getting-started/general-informationconcerning-patents\#heading- 5

US Patent and Trademark Office, 2017. What is a patent. FAQ. Accessed March 10, 2018. https://www.uspto.gov/help/patent-help\#1930

Vidal K, Van Den Brock P, Cavin E, et al. 2003. Osteoprotegerin in milk. US Patent and Trademark Office. Patent \#7749960.

http://patft.uspto.gov/netacgi/nphParser?Sect1 $=$ PTO1 $\&$ Sect $2=$ HITOFF $\& d=$ PALL $\& p=1 \& u=\% 2$ Fnetahtm $1 \% 2$ FPTO $\% 2$ Fsrchnum. htm\&r=1\&f=G\&l=50\&s1=7749960.PN.\&OS=PN/7749960\&RS = PN/7749960

Vidal K, Van Den Brock P, Cavin E, et al. 2005. Osteoprotegerin in milk. US Patent and Trademark Office. Patent \#7524815. http://patft.uspto.gov/netacgi/nph-

Parser?Sect $1=$ PTO1 $\&$ Sect $2=$ HITOFF $\& d=$ PALL $\& p=1 \& \mathrm{u}=\% 2$ Fnetahtml\% 2 FPTO $\% 2$ Frchnum. htm\&r=1\&f=G\&l=50\&s1=7524815.PN.\&OS=PN/7524815\&RS = PN/7524815 